\title{
STRENGTHENING OF THE SURFACE OF STEEL (9XФM) EXPOSED TO A HIGH-CURRENT ELECTRON BEAM
}

\author{
E.M. Prokhorenko ${ }^{1}$, V.V. Lytvynenko ${ }^{1}$, O.A. Melyakova ${ }^{1}$, Yu.F. Lonin ${ }^{2}$, A.G. Ponomarev ${ }^{2}$, \\ V.T. Uvarov', N.A. Shul'gin ${ }^{2}$, T.G. Prokhorenko ${ }^{3}$, R.I. Starovoytov', \\ A.I. Morozov ${ }^{5}$, S.R. Artemev ${ }^{5}$ \\ ${ }^{1}$ Institute of Electrophysics and Radiation Technologies, Kharkiv, Ukraine; \\ ${ }^{2}$ NSC “Kharkov Institute of Physics and Technology”, Kharkiv, Ukraine; \\ ${ }^{3}$ Kharkov National Automobile and Highway University, Kharkiv, Ukraine; \\ ${ }^{4}$ V.N. Karazin Kharkiv National University, Kharkiv, Ukraine; \\ ${ }^{5}$ National University of Civil Defense of Ukraine, Kharkiv, Ukraine \\ E-mail:forshad58@gmail.com
}

\begin{abstract}
9ХФМ steel was irradiated with a high-current electron beam. The high-current electron beam was obtained in the TEMP-A accelerator. The irradiation was performed for various samples of the material of a ball mill drum. Part of the samples were taken from the surface of the balls, which had different degrees of wear. Samples taken from the depth of the balls, which is equal to half the diameter, were also irradiated. Microhardness measurements, metallographic, and fractographic analysis were used to study mechanical and microstructural changes. In all cases, a change in hardness was detected. The degree of change in hardness is different for different samples. Based on fractographic analysis, using SEM microscopy, one of the mechanisms that contribute to increasing the surface hardness is determined. This mechanism is the cleaning of the surface of samples from impurities of phosphorus and sulfur using a high-current electron beam.
\end{abstract}

PACS: $87.55 \mathrm{~N}, 07.05 . \mathrm{Tp}, 44.90 .+\mathrm{c}, 61.80 . \mathrm{Fe}, 81.40 . \mathrm{Wx}$

\section{INTRODUCTION}

An important problem of any modern production is to improve production efficiency and increase its efficiency. These requirements apply to the work of the energy complex.

One of the components of the energy complex is a system for the production of electricity. The operation of this element substantially depends on the fuel component. Various types of fuel are used as fuel. A significant part of the electricity is generated at thermal power plants. Their fuel is gas, fuel oil and coal. Coal makes up a significant share in the fuel segment. The greatest heat transfer is obtained when it is burned in the form of a dust mixture. Therefore, the question of preparation of fuel mixture remains actual. This is facilitated by the fact that the quality of coal has sharply decreased.

The use of low-calorie coals also affects the efficiency of heat generation. The main unit in the coal mixture preparation system is a ball drum mill (BDM).

The principle of operation of the BDM is based on the impact of metal balls. In the work of the BDM, balls are consumables. The wear of balls occurs due to erasure and breaking [1]. During operation, there is a change in the hardness of the balls [2].

With a decrease in hardness, the strength characteristics also decrease. Therefore, the abrasion of the balls, their destruction is accelerated. Accordingly, operational performance is reduced. All this leads to an increase in the consumption of balls, a decrease in economic characteristics. The needs for balls are calculated from the expression [1]:

$$
G_{b}=D_{\text {real }} \cdot K_{f} \cdot \sum B_{f} .
$$

In this expression: $G_{b}-$ is the total fuel consumption; $D_{\text {real }}$ - the actual value of the specific wear of the balls; $K_{f}-$ is the coefficient of ash-content; $\Sigma B_{f}$ - fuel consumption. Based on this expression, the need for balls is determined. The $D_{\text {real }}$ coefficient is related to the hardness of the balls by the following expression:

$$
D_{\text {real }}=D_{\text {normat }} \cdot\left[1+\delta \cdot\left(H B_{\text {normat }}-H B_{\text {real }}\right)\right],
$$

where $D_{\text {normat }}-$ is the normative wear of the balls; $\delta-$ conversion factor (tabular); $H B_{\text {normat }}$ - normative value of hardness of balls; $H B_{\text {real }}$ - is the actual value of the hardness of the balls.

At the increase of hardness a normative wear falls down and the real wear falls down accordingly. Lowering of the real wear is instrumental in more protracted exploitation of balls and more high-quality grinding of fuel. All this together leads to lower fuel consumption and increased heat generation. Thus, increasing the hardness of the balls that are used as a working body is necessary.

It should be noted that the task of increasing the hardness of the balls makes it possible to solve a number of social problems. Among them, a decrease in the tension of human society through the solution of a number of environmental problems. Since a highly ground fuel mixture is burned with maximum efficiency, this reduces the formation of various wastes. Diminishing of wastes automatically reduces the ecological loading on an environment. The degree of loading of row of questions which cause tension in society goes down therefore. Thus, diminishing of the ecological loading allows to work out social problems.

For the increase of hardness of balls different ways are used. Among them: use of steels with large maintenance of carbon, cementation of surface, 
treatment of surface and modification of structure of surface by different ways.

An interesting and unique way to change and modify the structure of the material is the method of processing the material with various types of particles. A promising method is the surface treatment with a high-current electron beam (HCEB) [3-6]. To that end use the beam of speed-up electrons in the pulse-mode. A pulse width can change in an enough wide range temporal range from $10^{-8}$ to $10^{-5} \mathrm{~s}$. Energy of beam depends on the decided tasks and possibilities of the accelerating installation. It can vary in the range from tens of kiloelektronvolt to several megaelektronvolt. Current densities can reach $10^{4} \mathrm{~A} / \mathrm{cm}^{2}$. In this case, varying the beam parameters of beam to substantially change the surface characteristics.

\section{PURPOSE OF WORK}

Investigation of the effects that occur on the surface of 9ХФМ steel when exposed to a HCEB. The study of the surface hardness of metal balls during operation, which were made of 9ХФМ steel. Development of methods for IR-radiometric control, for thermal control of influence of a beam of accelerated electrons on a material. Investigation of changes in the surface structure of 9ХФМ steel that occurred after irradiation with a HCEB.

\section{THE MAIN PART}

The main material that was investigated was 9XФМ steel. It is a special carbon alloyed tool steel. It contains 0.8..0.9 carbon, $0.15 \ldots 0.35$ silicon, $0.3 \ldots 0.6$ manganese, $0.4 \ldots 0.7$ chromium, $0.13 \ldots 0.3 \%$ vanadium. Inclusions (not more than $0.3 \%$ ) of molybdenum, titanium, tungsten, copper, nickel are allowed. Slight additions (not more than $0.03 \%$ ) of sulfur and phosphorus are also possible. Additives of molybdenum, titanium, tungsten improve hardness characteristics. Inclusions (not more than $0.3 \%$ ) of molybdenum, titanium, tungsten, copper, nickel are allowed. Slight additions (not more than 0.03\%) of sulfur and phosphorus are also possible.

Additives of molybdenum, titanium, tungsten improve hardness characteristics. Additions of sulfur and phosphorus lower hardness of balls. From this steel the balls of BDM are made.

\section{MATERIALS AND METHODS}

Work on the study of changes in the structure of steel was carried out in several stages. At the first stage, the change in the surface hardness of the balls during their wear was studied [7]. For this, during the operation of the BDM, individual balls were removed. Balls were drawn at regular intervals from the start of loading. Therefore, the balls had varying degrees of wear. The sizes of the balls varied from $40 \mathrm{~mm}$ (new ball) to $15 \mathrm{~mm}$ (balls after unloading). Hardness was found for specific points on the surface of the ball. Hardness was measured with a PMT-3 hardness tester [8]. The methodology for determining the measurement points is described in [7].

In our case, balls with extremely high hardness and increased hardening depth were used. The deviations of the hardness value from this value at different points on the surface were no more than $20 \mathrm{MPa}$.

It was found that on the surface of new balls the maximum hardness was $9800 \mathrm{MPa}$. For the purity of the experiment, the balls were cut and a hardness measurement was carried out along the depth of the balls. In depth, the hardness was $9750 \mathrm{MPa}$. And the deviation in points is not more than $50 \mathrm{MPa}$. During operation, the hardness decreased.

Next, balls with diameters of $35,20,12 \mathrm{~mm}$ were studied. The measurement procedure was unchanged, as for the new ball.

It was found that for a ball with a diameter of $35 \mathrm{~mm}$, the surface hardness was $8100 \mathrm{MPa}$. In the central part - $9700 \mathrm{MPa}$. The minimum surface hardness was at the ball after unloading from a drum mill (diameter $12 \mathrm{~mm}$ ). It amounted to $6630 \mathrm{MPa}$. The hardness at the center of this ball was $8000 \mathrm{MPa}$.

The performed studies showed that the efficiency of the drum mill significantly depends on the hardness of the balls. To increase the hardness, a technique was used in which the ball material was treated with a HCEB of accelerated electrons. This technique is in demand, as it can be applied on an industrial scale.

The TEMP-A accelerator, which is located at the NSC KIPT (in the NSC "Kharkov Institute of Physics and Technology") [9], was used as a radiating device. The Descriptions of the beam were the following: the current of $2 \mathrm{kA}$, electron energy $\sim 300 \mathrm{keV}$, impulse duration $\tau_{p} \sim 5 \mu \mathrm{s}$. The current was measured using a Rogowksi coil. The beam has a diameter of $45 \mathrm{~mm}$ in cross section. The beam intensity has a Gaussian distribution. The peak fluence, was taken to be $250 \mathrm{~J} / \mathrm{cm}^{2}$. The pressure in the irradiation chamber was $10^{-5}$ Torr.

\section{CONDUCTING EXPERIMENTS AND DISCUSSION OF RESULTS}

To process samples with a HCEB of accelerated electrons, these samples must be presented in a special form. For this purpose, the balls were cut into pucks $1.2 \mathrm{~mm}$ thick. All studies were performed on these pucks.

After processing with a beam, samples were cut from part of the pucks to study the material for plasticity. They had a length of $20 \mathrm{~mm}$, a capture width of $3.2 \mathrm{~mm}$, and a width of the bursting part of $0.9 \mathrm{~mm}$. The thickness of the samples is $0.4 \mathrm{~mm}$. Researches on plasticity were carried out on a tensile testing machine break. The pucks and samples are shown in Fig. 1.

During the irradiation of samples with a HCEB, IRradiometric diagnostics of the thermal field was carried out [9-12]. This made it possible to control the state of the sample during processing. 


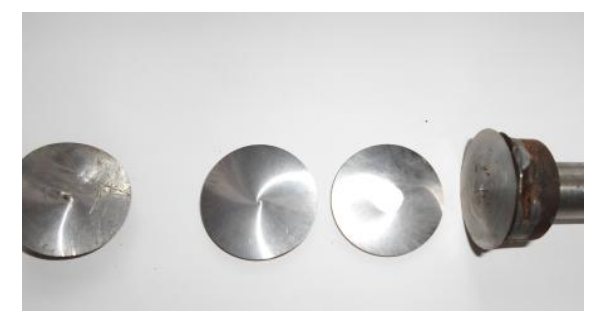

$a$

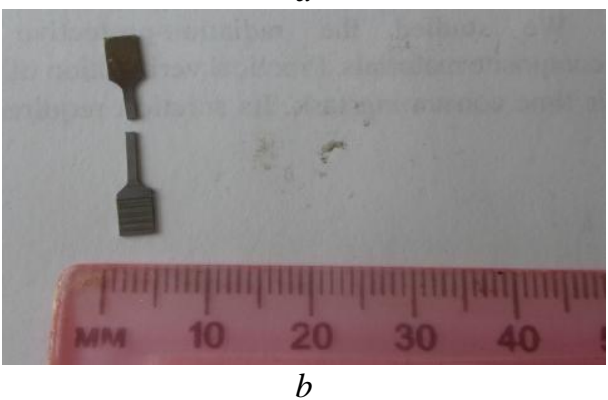

Fig. 1. Pucks and a sample after a tensile testing machine

Original appearance the pucks after processing on the TEMP-A accelerator, together with the target, is shown in Fig. 2.

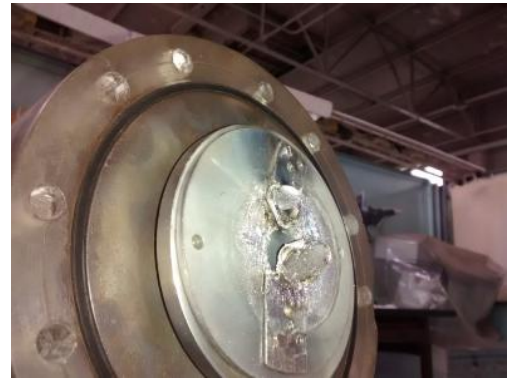

Fig. 2. Pucks after an irradiation

After processing the samples with HCEB, measurements were made of the surface hardness of the samples. The least increase of value of hardness was for new balls. The largest increase in hardness was observed for samples that were made from previously used balls. In numerical terms, this has such meanings. For the case of a new ball, the initial hardness was $9800 \mathrm{MPa}$. After beam treatment, the hardness increased to $10100 \mathrm{MPa}$. This value significantly exceeds the value of hardness in accordance with regulatory requirements. The hardness in the central part of the new ball, at a distance of half the diameter, did not change and had a value of $9750 \mathrm{MPa}$. Those no increase in hardness was observed inside the ball. This is natural, since the HCEB performs surface treatment. For a ball with a diameter of $20 \mathrm{~mm}$, the hardness increased to $9800 \mathrm{MPa}$. With hardness before processing $7500 \mathrm{MPa}$. The maximum increase in hardness was observed for a ball with a diameter of $12 \mathrm{~mm}$. Its hardness after processing is $9600 \mathrm{MPa}$. Hardness before processing $6630 \mathrm{MPa}$.

Researches, conducted on a break machine, exposed a change in the structure of steel also. A decrease in plasticity was found for all samples. At break, all samples require more force. So the sample, which was made from a new ball, required a $144 \mathrm{kG} / \mathrm{mm}^{2}$ force for the break. Whereas without irradiation, this indicator was $140.6 \mathrm{kG} / \mathrm{mm}^{2}$. For a sample made of a ball with a diameter of $20 \mathrm{~mm}$, these values were 136 and $122 \mathrm{kG} / \mathrm{mm}^{2}$. The maximum value of the decrease in plasticity is observed for a sample made of a ball with a diameter of $12 \mathrm{~mm}$. After irradiation, the force of break was $130 \mathrm{kG} / \mathrm{mm}^{2}$, whereas before processing, $104 \ldots 108 \mathrm{kG} / \mathrm{mm}^{2}$.

When metals are irradiated with a HCEB, with certain characteristics, surface hardening is possible [3, $4,6,7,13,14]$. In this case, work several mechanisms that are responsible for hardening.

Among them may be: the transformation of the surface layer to martensite, carbonization, the appearance of oxides, cleaning the surface layer from various inclusions. When cleaning the surface, evaporation of less refractory inclusions occurs, which increases hardness.

In the process of irradiation of a metal sample with a HCEB, its surface is rapidly heated. In this case, in the surface layer, areas of molten metal appear. Due to the vaporized elements, a plasma cloud forms above the surface of the sample. Various effects may appear as a result of crystallization of the melt on a colder basis. Also, as a result of the start-up effect on the sample, various defects can be formed $[4,6,13,14]$. When the thickness of the sample is less than three depths of penetration of the beam, it is possible its destruction. As a result of irradiation of the sample, several zones with different structures are formed. The quenching zone is located on the surface of the sample. Under the surface, below the quenching zone, there is a zone that has undergone considerable thermal influences and melting. And then there is a zone that has been subjected to significant dynamic loads. The two upper zones on the surface of the sample are caused by the influence of temperature fields and cooling rates. The lower zone ends in the volume of unirradiated material. It is formed due to the occurrence of defects that are caused by the action of shock waves. Shock waves are generated due to the ejection of molten material from the surface. And also due to uneven heating of the area of influence of the beam and basis of the sample.

The material evaporates from the surface of the sample. First of all, elements with a low melting point evaporate. Thus, there is cleaning of surface. To determine the mechanisms due to which the change in the surface hardness of the balls occurs, fractographic studies were performed. The studies were carried out using raster electron microscopy. Used JEOL JSM-840.

The surface of the samples after rupture was examined. Samples were taken in pairs from each ball, before and after irradiation. Studies were carried out on the state of the surface of the samples. Based on the analysis of fractograms [15], several mechanisms were discovered that contribute to the increase in hardness.

Recrystallization has a significant effect on increasing the hardness of the surface layer of samples. In Fig. 3 shows fractograms of the fracture surfaces of samples that were made of steel balls before irradiation. The balls had varying degrees of wear. 


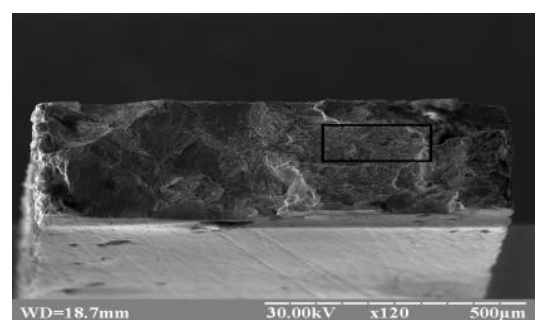

$a$

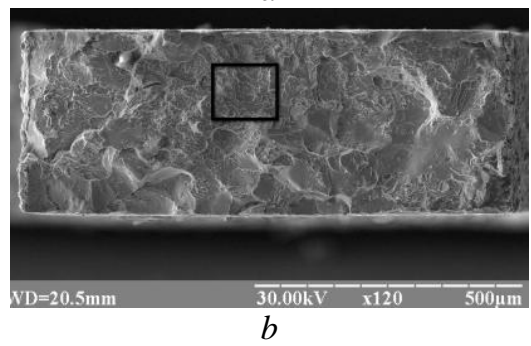

Fig. 3. Fractograms of the break surfaces of samples made from balls with a diameter: $a-20 ; b-12 \mathrm{~mm}$. Before an irradiation

In Fig. 3,a shows a fractogram of the surface of the ball (diameter $35 \mathrm{~mm}$ ) before processing on the accelerator. In Fig. 3,b shows a fractogram of the surface of the ball (diameter $12 \mathrm{~mm}$ ), also before processing on the accelerator. For comparison, we present fractograms of the fracture surface after treatment with a HCEB (Fig. 4).

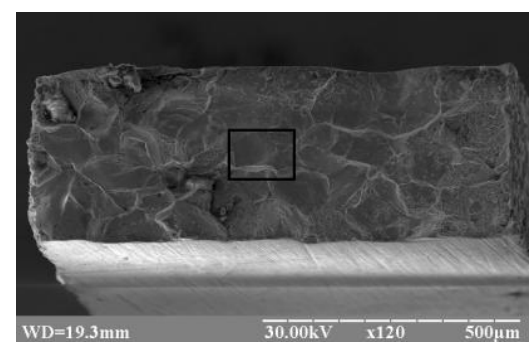

$a$

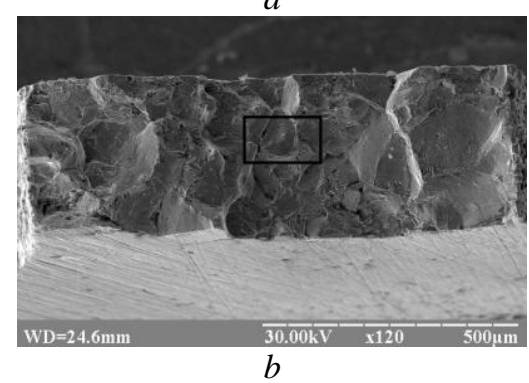

Fig. 4. Fractograms of the break surfaces of samples made of balls with a diameter:

$a-20 ; b-12 \mathrm{~mm}$. After irradiation

Comparing the fractograms presented in Figs. 3 and 4 immediately observe significant differences. Before an irradiation the structure of break had a viscid form. Grain structure is observed only in certain areas. The grains that can be identified are $200 \times 150 \mu \mathrm{m}$ in size. The viscid break area was over $60 \%$ of the surface (ball with a diameter of $20 \mathrm{~mm}$ ) and more than $80 \%$ of the surface (ball with a diameter of $12 \mathrm{~mm}$ ). Enlarged fragments of the viscid fracture surface are shown in (Fig. 5).

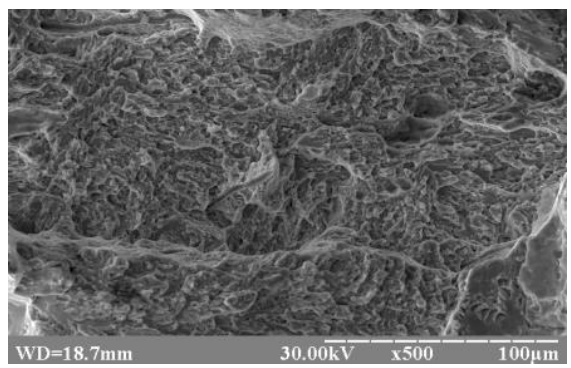

$a$

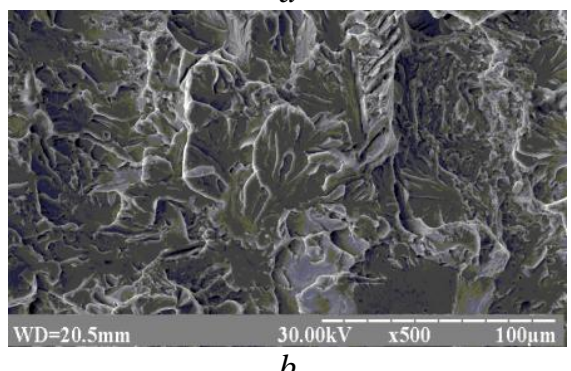

Fig. 5. Enlarged areas of fractograms of the break surfaces of the samples before irradiation, made of balls with a diameter: $a-20 ; b-12 \mathrm{~mm}$.

Before an irradiation

In their structure, viscid breaks in both samples are similar. Elongated micropore pits predominate. During operation, the balls constantly struck at the the material being ground. Upon impact, dislocations appear in the samples. Their accumulation and confluence leads to the appearance of microdefects. Further accumulation of defects occurs in several planes. The break is accompanied by the formation of cavitys. This is especially noticeable for a $20 \mathrm{~mm}$ ball (see Fig. 5,a). For samples that were obtained from a $12 \mathrm{~mm}$ ball (see Fig. 5,b), the structure of the break surface is slightly different.

The surface is represented by flatter ledges. This development of the break is possible [15] with the fatigue state of the material. This state of the material occurs during prolonged cyclic exposure to shock loads. The characteristic features of the fatigue state are elongated flat surfaces of the facets of quasi spalling. The flat surfaces of facets do not have the expressed direction. That testifies to evenness of influence of the loadings.

After irradiation, the structure of the fracture surface differs significantly from the structure of the fracture surface prior to irradiation. On the surface, we observe a significant number of grains. The surface view is shown in Fig. 6.

From the images of fractograms, we observe that the break passed through the grains. An insignificant part of the break surface is intergranular break. The grain size was $50 \times 70$ and $50 \times 50 \mu \mathrm{m}$. We observe a structure that has a grain size smaller than before irradiation. The cause of the formation of the grain structure is recrystallization. Under the action of a HCEB, the surface layer of the sample is rapidly heated. Heating is accompanied by the melting of individual sections of the surface. 


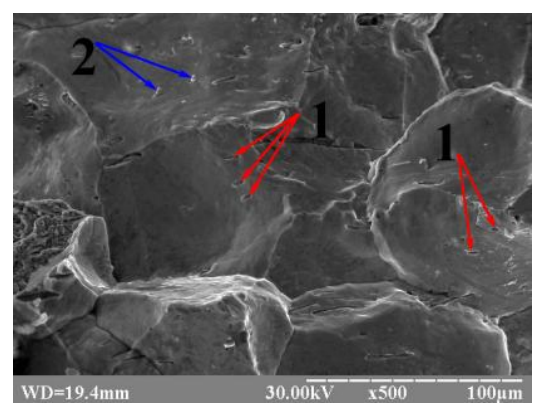

a

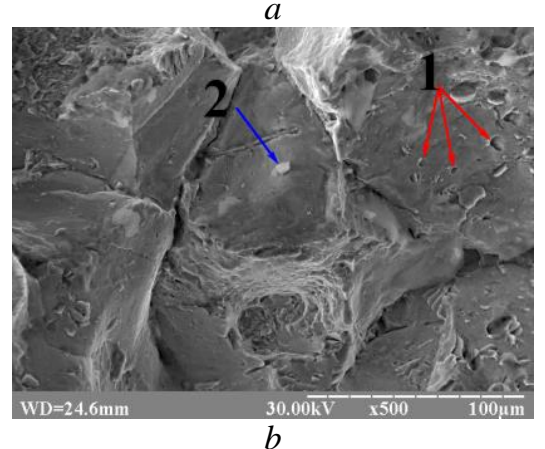

Fig. 6. Enlarged sections of fractograms of the break surfaces of samples made of balls with a diameter: $a-20 ; b-12 \mathrm{~mm}$. After irradiation

Melting takes place in a thin surface layer. Heating is very fast. The heat from the heated areas does not have time to spread inside the sample. Therefore the melting region is in contact with the cold base. Instant cooling takes place, and crystallization of the molten part of the material. A new surface zone is formed, which has a fine-grained crystalline structure. This zone has increased hardness. The recrystallized region is shown in Fig. 6.

Also, melting is accompanied by evaporation of the molten material. In this case, it is possible the evaporation of various additives, which have a lower melting point than the basis of material of surface. This is the mechanism of surface cleaning under the action of a HCEB of accelerated electrons.

The issues of cleaning materials under the influence of radiation were considered in a number of works. In particular, it was shown in [14], due to the purification of the material, the hardness can increase. This implies purification using a HCEB of accelerated electrons. The degree of increase in hardness can reach $10 \%$. However, excluding this mechanism from consideration will be incorrect. It was shown in [16] that sulfur and phosphorus inclusions evaporated. These additives reduce hardness.

In our case, to confirm this statement, we consider the images of fractograms shown in Fig. 6. They show the break surfaces of the samples that were irradiated. The analysis is carried out using fractograms, which are given in [15]. The fractogram data are well described and explained. Therefore, they can be a standard. On the surface of grains, we observe manifestations of various defects, inclusions, and features. So on the surface we find micropores that are formed in the region where the manganese inclusions are located (Point 1). To a small extent, inclusions of chromium oxides are present (Point 2).
These inclusions contribute to increased hardness. However, we do not observe characteristic manifestations for inclusions with a low melting point. These are compounds of phosphorus and sulfur. These compounds were present in the surface layer prior to irradiation. After irradiation, they are not observed. Evaporation of these inclusions during irradiation may be the cause of this effect. Therefore, there is an effect of cleaning the surface layer of the sample material. And accordingly, it affects the increase in hardness. Therefore, when studying the issues of increasing the hardness of materials, this effect must also be taken into account.

Thus, it can be argued that several factors influence the change in the surface hardness of the balls, which increased as a result of irradiation with a HCEB. Among them, the effects of recrystallization, the effect of cleaning the surface of the material

\section{CONCLUSIONS}

1. Steel (9ХФМ) balls were irradiated with HCEB.

2. The effects of increasing the hardness of the surface of the balls were studied. These effects were observed when irradiated with HCEB.

3. It was found that the hardness of the surface layer of irradiated samples is significantly higher than the surface hardness of unirradiated samples. An increase in the force of viscid break was found for irradiated samples, compared with unirradiated samples.

4. The paper shows that the effect of increasing the hardness of the surface layer of samples is composite and includes various mechanisms.

5. Several characteristic mechanisms have been identified that contribute to increasing the hardness of the surface layer. The mechanisms were determined using the analysis of fractograms of surface of break.

6. It is concluded that recrystallization of the metal surface and purification of the surface layer material by a HCEB contribute to the process of increasing strength.

\section{REFERENCES}

1. V.T. Levit. Ardor preparation on thermal powerstations. M.: "Energ", 1991, 384 p.

2. GOST 7524-89. Balls the steel grindings for ball mills. [Text] / 01-02. 1989-01-02. M: "Stand.”, 26 p.

3. Jr.S. Humphries. Principles of high current electron beam acceleration // Nuclear Instruments and Methods in Physics Research Section A: Accelerators, Spectrometers, Detectors and Associated Equipment. 1987, v. 258, issue 3, p. 548-565.

4. V.V. Bryukhovetskiy, N.I. Bazaleev, V.F. Klepikov, V.V. Litvinenko, O.E. Bryukhovetskay, E.M. Prokhorenko, V.T. Uvarov, A.G. Ponomar'ov. Features of gelation of surface of industrial aluminium alloy 6111 in the area of influence of impulsive bunch of electrons in the mode of premelting // Problems of Atomic Science and Technology. 2011, N 2(72), p. 2832.

5. V.F. Klepikov, E.M. Prokhorenko, V.V. Lytvynenko, S.E. Donets, V.N. Robuk, T.G. Prokhorenko, V.T. Uvarov, A.G. Ponomarev, Yu.F. Lonin. The use of high-current relativistic electron beams for the study of the effects of ionizing radiation on materials storage 
RAW // Problems of Atomic Science and Technology. 2016, N 2(102), p. 72-77.

6. C. Dong et al. Surface treatment by high current pulsed electron beam // Surface and Coatings Technology. 2003, v. 163-164, p. 620-624.

7. E.M. Prokhorenko, V.F. Klepikov, V.V. Lytvynenko, P.A. Khaymovich, N.A. Shul'gin, A.I. Morozov. Diagnostics of processes of wear of materials of balls drum mills // Eastern European Journal of Enterprise Technologies. 2015, N 1/5, v. 73, p. 14-20.

8. ASMA: Manual of PMT-3 microhardness testing indenter. 2018, $17 \mathrm{p}$.

9. V.T. Uvarov et al. Radiation acoustic control over the thermal parameter of construction materials irradiated by intense relativistic electron beam // Phys. of Part. and Nucl. Latter. 2014, v. 11, N 3, p. 274-281.

10. E.M. Prokhorenko, V.F. Klepikov, V.V. Lytvynenko, N.I. Bazaleyev, I.I. Magda, T.G. Prokhorenko, A.I. Morozov. Application of ir-radiometric diagnostics for control of vacuum connections of electrophysical installations // Problems of Atomic Science and Technology. 2018, N 1(113), p. 212-217.

11. V.F. Klepikov, E.M. Prokhorenko, V.V. Lytvynenko, A.A. Zaharchenko, M.A. Hazhmuradov. Control of macroscopic characteristics of composite materials for radiation protection // Problems of Atomic Science and Technology. 2015, N 2(96), p. 193-196.

12. E.M. Prokhorenko, V.V. Lytvynenko, A.A. Zaharchenko, M.A. Hazhmuradov, T.G. Prokhorenko. Studying the changes in the characteristics of radiationprotective composition materials in dependence on homogeneity of distributing of metal components // Problems of Atomic Science and Technology. 2019, N 2(120), p. 121-126.

13. J.X. Zou et al. Selective surface purification via crater eruption under pulsed electron beam irradiation // Applied Physics Letters. 2006, v. 89, issue 4, p. 1904-1913.

14. S.Z. Hao et al. Microstructure evolution occurring in the modified surface of $316 \mathrm{~L}$ stainless steel under high current pulsed electron beam treatment // Applied Surface Science. 2007, v. 253, issue 12, p. 5349-5354.

15. Dzh. Fellouz. Fraktography and Atlas of fraktographs. Ohio: "Metals park", 1982, 489 p.

16. J.X. Zou et al. Cross-sectional analysis of the graded microstructure in an AISI D2-steeltreated with low energy high-current pulsed electron beam // Applied Surface Science. 2009, v. 255, issue 9, p. 4758-4764.

Статья поступила в редакциию 01.11.2019 2.

\title{
УПРОЧНЕНИЕ ПОВЕРХНОСТИ СТАЛИ (ФХФМ) ПРИ ВОЗДЕЙСТВИИ СИЛЬНОТОЧНОГО ЭЛЕКТРОННОГО ПУЧКА
}

\author{
Е.М. Прохоренко, В.В. Литвиненко, Е.А. Мелякова, Ю.Ф. Лонин, А.Г. Пономарёв, В.Т. Уваров, \\ Н.А. Шульгин, Т.Г. Прохоренко, Р.И. Старовойтов, А.И. Морозов, С.Р. Артемьев
}

Сталь 9ХФМ была облучена сильноточным электронным пучком, который получен в ускорителе ТЕМПА. Облучение проводили для различных образцов материала шара барабанной мельницы. Часть образцов взята с поверхности шаров, которые имели различную степень износа. Также облучали образцы, взятые из глубины шаров, которая равна половине диаметра. Для изучения механических и микроструктурных изменений применяли измерения микротвердости, металлографический и фрактографический анализы. Во всех случаях обнаружено изменение твердости. Для различных образцов степень изменения твердости различна. На основе фрактографического анализа с использованием РЭМ-микроскопии определен один из механизмов, который способствует повышению твердости поверхности. Этим механизмом является очистка поверхности образцов с помощью сильноточного пучка электронов от примесей фосфора и серы.

\section{ЗМІЦНЕННЯ ПОВЕРХНІ СТАЛІ (9ХФМ) ПРИ ДІЇ СИЛЬНОСТРУМОВОГО ЕЛЕКТРОННОГО ПУЧКА}

\section{С.М. Прохоренко, В.В. Литвиненко, О.А. Мелякова, Ю.Ф. Лонін, А.Г. Пономарьов, В.Т. Уваров, М.А. Шульгін, Т.Г. Прохоренко, Р.І. Старовойтов, А.І. Морозов, С.Р. Артем'єв}

Сталь 9ХФМ була опромінена сильнострумовим електронним пучком, який отримано в прискорювачі ТЕМП-А. Опромінення проводили для різних зразків матеріалу кулі барабанного млина. Частина зразків була взята $з$ поверхонь куль, які мали різний ступінь зносу. Також опромінювали зразки, узяті з глибини куль, яка була рівна половині діаметра. Для вивчення механічних і мікроструктурних змін застосовували виміри мікротвердості, металографічний і фрактографічний аналізи. У всіх випадках виявлена зміна твердості та пластичності. Для різних зразків ступінь зміни твердості та пластичності різна. На основі фрактографічного аналізу з використанням РЕМ-мікроскопії визначений один з механізмів, який сприяє підвищенню твердості поверхні. Цим механізмом $є$ очищення поверхні зразків за допомогою сильнострумового пучка електронів від домішок фосфору і сірки. 